\title{
Forearc Slope Deformation above the Japan Trench Megathrust: Implications for Subduction Erosion
}

\section{Authors:}

Brian Boston $^{1, *}$

bboston@hawaii.edu

Gregory F. Moore ${ }^{1}$

gmoore@hawaii.edu

Yasuyuki Nakamura ${ }^{2}$

yasu@jamstec.go.jp

14

Shuichi Kodaira $^{2}$

16 kodaira@jamstec.go.jp

$17 *$ Corresponding author

$18{ }^{1}$ Department of Geology and Geophysics, University of Hawai‘i at Mānoa, 1680 East-West

19 Road, Honolulu, HI 96822, USA

20

${ }^{2}$ Research and Development Center for Earthquake and Tsunami, Japan Agency for Marine-

22 Earth Science and Technology, 3173-25 Showa-machi, Kanazawa-ku, Yokohama 236-0001,

23 Japan 


\section{Abstract}

33 Subduction erosion is a commonly invoked model that is used to explain the tectonic subsidence

34 of the Japan Trench forearc slope, although other models have explained the morphology and

35 history of the margin. New multichannel seismic reflection and bathymetric data collected after

36 the 2011 Tohoku earthquake provide the opportunity to investigate the detailed structure of the

37 overriding plate near the earthquake epicenter and obtain new constraints on tectonic models. We

38 use regional-residual separation of the local bathymetry to constrain fault scarp extents and local

39 landward-dipping forearc basins. Seismic images of these basins clearly show landward-dipping

40 horizons in the shallow section. The strata in these basins imply a different mechanism for

41 formation than the surrounding forearc slope, and we propose that these basins formed from

42 local uplift. A regional basal unconformity mapped $\sim 150 \mathrm{~km}$ along-trench has highly variable

43 relief, indicating that forearc slope subsidence occurs at multiple wavelengths in response to

44 multiple different sources. We characterize the upper to middle slope transition and propose that

45 this region may be the landward limit of major subduction erosion and also the main region for

46 large mass wasting. Normal faults found in this setting have maximum lengths of $\sim 20 \mathrm{~km}$,

47 limiting their role in margin processes. Our results place constraints on the extent of major

48 subduction erosion at the Japan Trench margin, and indicate that subduction erosion should be

49 revisited as the sole model of formation to include additional tectonic processes. 


\section{Introduction}

The great $2011 \mathrm{Mw} 9.0$ Tohoku earthquake produced large coseismic slip of 30-60 m

53 (e.g., Simons et al., 2011; Ide et al., 2011; Fujii et al., 2011; Chu et al., 2011; Wei et al., 2012),

54 creating a tsunami with local coastal heights as great as $40 \mathrm{~m}$ (Mori et al., 2011). The earthquake

55 occurred where the Cretaceous Pacific Plate subducts beneath northern Honshu (Fig. 1). This

56 subduction zone is considered an end-member case erosional margin (von Huene and Culotta,

57 1989; von Huene et al., 1994) defined by subsidence and normal faulting throughout the forearc

58 slope. This tectonic erosion is thought to remove material from the base of the upper plate

59 through hydrofracturing (von Huene et al., 2004). However, part of the subsidence may be

60 caused by changes in plate convergence rates that alter the plate boundary geometry (Regalla et

61 al., 2013). The morphology of the overriding plate plays a direct role in tsunamigenesis, where

62 horizontal displacement of a steep slope can vertically displace the water column contributing to

63 tsunami formation (Tanioka and Satake, 1996), and this type of seafloor motion is argued to have

64 increased the tsunami height from the Tohoku earthquake (Hooper et al., 2013), revealing the

65 importance of morphology to the margin. The coseismic slip area of large earthquakes generally

66 correlates with the area with overlying forearc basins (Song and Simons, 2003; Wells et al.,

67 2003; Fuller et al., 2006), but the Japan Trench margin lacks large forearc basins. Gravity

68 analysis for the Japan Trench megathrust region indicates that the overlying plate still contributes

69 to plate coupling and the seismogenic behavior of the margin (Bassett et al., 2016). Further

70 characterization of forearc slope deformation in regions, such as the Japan Trench, will highlight

71 upper plate contributions to large earthquakes and tsunami generation.

The structure and lithology of the forearc region of northeastern Japan have been

73 previously investigated by drilling and seismic surveys (e.g., Scientific Party, 1980; von Huene 
74 and Arthur, 1982; Tsuru et al., 2002; Suyehiro et al., 2003). In this region, the upper slope is

75 underlain by $\sim 2 \mathrm{~km}$ thick sequences of Neogene sediments (Fig. 1) dated by drilling during Deep

76 Sea Drilling Project (DSDP) Legs 56 and 57 (Scientific Party, 1980). A regional unconformity

77 separates silicified Cretaceous basement rocks from the overlying forearc slope strata (Scientific

78 Party, 1980). This unconformity is interpreted to be a subaerial erosional surface marking sea

79 level in the Miocene (von Huene et al., 1982), and we identify it as the regional basal

80 unconformity (RBU). Below the RBU are Cretaceous claystones later accreted to form an

81 accretionary prism (von Huene et al., 1982). The youngest overlying strata extend trenchward to

82 a prominent boundary, against which a small frontal accretionary prism has formed along the

83 lower slope (Fig. 1) (von Huene et al., 1994; Tsuru et al., 2000). Forearc basins have been found

84 throughout the upper slope (Arai et al., 2014; von Huene and Arthur, 1982), with landward

85 dipping forearc basins potentially forming by slip on a listric normal fault on the landward edge

86 of the basin (von Huene and Culotta, 1989). The shallow Neogene strata are largely

87 characterized by normal faults that extend to the seafloor (Tsuru et al., 2000; Tsuru et al., 2002).

88 Regional seismic reflection surveys show that the shallow structure in the northern Japan Trench

89 forearc is similar throughout the margin (Tsuru et al., 2002; von Huene et al., 1994). However,

90 north-south wide-angle seismic refraction and reflection surveys document along-trench

91 structural variations within the overlying plate that correlate with the segmentation of the

92 interplate coupling (Fujie et al., 2013; Hayakawa et al., 2002). Observed seafloor fault scarps

93 within the lower half of the middle prism are suggested to have been created during coseismic

94 slip of the Tohoku earthquake (Tsuji et al., 2013). The frontal prism, penetrated at Integrated

95 Ocean Drilling Program (IODP) Site C0019 (Fig. 1), shows moderately- to steeply-dipping

96 accreted mudstones above a plate boundary fault zone, $\sim 5-15 \mathrm{~m}$ thick (Kirkpatrick et al., 2015). 
Although many seismic reflection studies since the Tohoku earthquake have focused on

98

99

100

101

102

103

104

105

106

107

108

109

110

111

112

113

114

115

116

117

118

119

imaging the trench axis and deformation front, which defines the seaward boundary of the frontal

prism (e.g., Kodaira et al., 2012; Nakamura et al., 2013; Boston et al., 2014), the aim of this

paper is to investigate the upper forearc slope using seismic reflection surveys collected in 2011

and 2013 in order to delineate the structure of the margin. Previous surveys have studied the full

margin by using widely spaced reflection lines (e.g., Arai et al., 2014; Tsuru et al., 2002). We

expand on these studies by focusing near the Tohoku epicenter with a denser survey grid that

allows us to investigate in greater detail the margin's complex morphology and history. In this

paper, we present data from 15 seismic reflection lines combined with regional bathymetry to

characterize the Japan Trench RBU, deformation styles within the forearc basins, and normal

fault connectivity particularly in the middle to upper forearc slope to determine how the

overriding plate has evolved over this megathrust region.

\section{Methods}

This project focuses on an along-trench transect above the Tohoku megathrust earthquake in the central Japan Trench region and utilizes bathymetry and seismic reflection surveys. We used a compilation bathymetry grid of the Japan Trench region from Boston et al., 2014 (Fig. 1).

We applied a directional median filter that divides the filter circle into "bow tie" sectors and computes the median value for each sector (Kim and Wessel, 2008), and performed regionalresidual separation of the bathymetry using a range of filter widths of $20 \pm 10 \mathrm{~km}$ that reduced the estimated median absolute deviation for the grid. This filtering technique prevents a biased median due to a sloping regional trend, allowing for an accurate view of both the isolated shortlength-scale features and the background regional bathymetry. We produced maps of regional bathymetry, median absolute deviation, regional slope azimuth, and residual bathymetry (Fig. 2). 
We processed and analyzed 15 seismic reflection dip lines collected during four surveys

121 in 2011 and 2013 on R/V Kairei (Fig. 1). The seismic system used a 6,000 m long, $12.5 \mathrm{~m}$ group

122 interval, 444-channel hydrophone streamer cable to record seismic returns at a sampling interval

123 of $2 \mathrm{~ms}$. The source was a 7,800 in ${ }^{3}$ air-gun array fired at $50 \mathrm{~m}$ intervals. This acquisition

124 geometry generated a common mid-point (CMP) interval of $6.25 \mathrm{~m}$. The seismic profile grid has

125 an average along-strike line spacing of $\sim 10 \mathrm{~km}$. MCS processing included a conventional

126 workflow of trace edit, CMP binning, predictive deconvolution, velocity analysis, normal

127 moveout correction, radon filter, CMP stacking, and band-pass filter (Yilmaz, 2001). We

128 performed Kirchhoff post-stack depth migration (PoSDM) on lines D03, TH04, D05, D06, D08,

129 D09, D13, D15, and D16. Our velocity model uses velocities based on previous local refraction

130 and reflection studies (e.g., Tsuru et al., 2000) for the initial velocity model. We iterated the

131 velocity model through PoSDM to a final seismic depth section that produced the clearest image.

132 Pre-stack depth migration (PSDM) was applied to lines D02, JFD1, TH03, D11, D17, and D19,

133 following the methods previously applied to line JFD1 (Nakamura et al., 2014) and iterating

134 through horizon-based residual velocity analysis to produce a precise velocity model. We applied

135 automatic gain control to all the final seismic images to enhance deeper reflections.

\section{3. Results and Interpretations}

\section{3.1. Tilted Forearc Basins}

Bathymetry analysis provides new insights into the modern forearc basin processes of the

139 Japan Trench forearc slope (Fig. 2). The median absolute deviation provides uncertainty bounds

140 of the regional-residual bathymetry separation where multiple length-scale features are present.

141 Because the forearc slope contains a continuum of length scales, we selected a final range of

142 filter widths, $20 \pm 10 \mathrm{~km}$, that included forearc basin features but reduced the median absolute 
143 deviation. The separation results are assessed by the spatial distribution of the median absolute

144 deviation between filter widths, and we find a generally low deviation except at a few locations

145 such as the trench axis (Fig. 2B). Calculating the slope azimuth of the regional bathymetry shows

146 a general seaward dip, except in two forearc basins (Fig. 2C). Instead, these two forearc basins

147 have a seafloor that dips landward, suggesting a different process created these basins than the

148 surrounding forearc slope. Whereas the landward-dipping portion of the northern forearc basin

149 covers the majority of the basin's area $(\sim 20 \times 30 \mathrm{~km})$, the southern basin landward-dipping

150 portion is small and more linear.

151 Seismic constraints validate our identification of these basins and provide clear images of

152 tilted basins (Fig. 3). We divided the sedimentary column into three seismic units based on

153 previous interpretations in the area (Arai et al., 2014) and performed a detailed line-to-line

154 comparison of the sequences to establish continuity. Seismic lines D08 and D16 image the two

155 landward dipping basins, whereas seismic line D11 reveals a buried landward dipping basin but

156 with seaward dipping seafloor (Figs. 3 and 4). Line D08 images the southern basin and shows the

157 bottom horizons onlapping onto the RBU, indicating the unconformity locally had high relief

158 when buried by sediment. Normal faults are found to offset the seafloor within this area,

159 indicating active deformation. However, the majority of normal faults do not offset the seafloor

160 or shallow strata, including the overlying basin, indicating that these faults are currently not

161 active. We do not find any clear evidence for differential compaction altering the dip direction of

162 the seafloor, as the small amount of sediment in this basin makes this unlikely. Line D16 shows a

163 different style of landward-dipping strata in the northern basin (Figs. 3 and 4). Here, both the

164 oldest and youngest horizons have been tilted landward, with older, deeper horizons dipping

165 more steeply. Additionally, the RBU follows the same geometry has the deeper overlying strata. 
166 Folded horizons are found on the eastern edge of the tilted region. Normal faults are found

167 beneath the basin, but do not appear within the basin. Along seismic line D11, the seafloor

168 currently dips seaward but deeper horizons follow the geometry of an anticlinal RBU. This

169 formed a small forearc basin in the overlying strata. These seismic lines show both a current and 170 a past history of landward tilted forearc basins.

\section{3.2. The Regional Basal Unconformity and Slope Sediments}

The RBU has recorded the Japan Trench forearc subsidence and deformational history

173 since the period it marked sea level. We image the RBU within a region extending $\sim 150 \mathrm{~km}$

174 along the trench and $\sim 110 \mathrm{~km}$ perpendicular to the trench. The unconformity appears as a

175 positive high-amplitude reflection boundary (e.g., Fig. 1C) separating overlying continuous

176 reflections from chaotic basement reflections, consistent with previous seismic reflection

177 interpretations throughout the margin (e.g., von Huene et al., 1982; Tsuru et al., 2002). The

178 mapped RBU includes both confident and less confident interpretations, where poor signal return

179 or the local geology reduce deeper image quality. The seaward extent of the unconformity is

180 difficult to locate owing to poor image quality there. DSDP Legs 56 and 57 drilled through the

181 basal unconformity outside our survey area (Scientific Party, 1980), but DSDP Site 584 was

182 unable to penetrate to that depth (Shipboard Scientific Party, 1986). Ocean Drilling Program

183 (ODP) Site 1150 is near seismic line D19, and ODP Site 1151 is near seismic line D15 (Fig. 1).

184 Dating from these two sites indicate the upper sediments are Miocene and younger in age,

185 however, the distance between lines and well sites is too significant for accurate correlation in

186 this tectonic setting (Suyehiro et al., 2003). Neither of these ODP sites reached the deeper RBU.

187 The relatively small seismic grid spacing, compared to the $>100 \mathrm{~km}$ spacing of previous studies,

188 allows for a focused study area of the RBU along the Japan Trench margin. 

view of the RBU (Fig. 5A), from gridding and smoothing of seismic interpretations with a $25 \mathrm{~km}$

191 Gaussian filter, and an isopach map of the sedimentary fill above the unconformity (Fig. 5B), 192 created using the filtered bathymetry grid and the smoothed unconformity grid. The RBU 193 exhibits $>1 \mathrm{~km}$ relief within our survey area, whereas the seafloor remains fairly consistent on 194 the western portion of the survey. Both high and low relief features with variable wavelengths 195 are found throughout many seismic lines. RBU depressions of $\sim 1.5 \mathrm{~km}$ deep, $<40 \mathrm{~km}$ wide and $196 \sim 30 \mathrm{~km}$ along strike are some of the largest. However, broader antiformal morphology is also 197 present. Many features of the RBU are not present line-to-line indicating their length is less than 198 the seismic grid interval. The subducting plate's structures are not found to cause consistent 199 deformation of the RBU (Figs. 1 and 5C), unlike the processes found near the trench, where 200 subducting normal faults clearly deform the overriding plate (e.g., Boston et al., 2014). The RBU 201 shows a uniform increase in depth towards the east at $\sim 50 \mathrm{~km}$ landward of the deformation front, 202 generally following the trend of the deformation front's trace (Fig. 5). The isopach map reveals 203 that the slope fill varies in thickness by $\sim 3000 \mathrm{~m}$ and thins towards its seaward edge, generally 204 within $50 \mathrm{~km}$ of the deformation front (Fig. 5). This thinning pattern is consistent throughout all 205 the lines. This is also the location of a break in seafloor dip to the middle slope.

206 3.3 Characteristics of the Upper to Middle Slope Transition 
212 analysis of both short-length-scale bathymetric features and the regional bathymetry at the upper

213 to middle slope transition. The residual bathymetry largely highlights fault scarps, channels, and

214 small-scale basins. Regional seafloor features are interpreted using both the bathymetry and

215 seismic data to constrain structure types (Figs. 6 and 7). We find the lateral continuity of normal

216 fault scarps is as great as $\sim 20 \mathrm{~km}$ along strike, but commonly is only $\sim 10 \mathrm{~km}$. Anticlines or

217 ridges are most commonly found near the lower slope but are also located further landward and

218 interspersed between normal faults. This fault pattern indicates the upper to middle slope

219 transition is not solely a normal fault boundary.

220 Our seismic lines show that the transition between the upper and middle slope is

221 complex, and contains not only normal faults expected from a subduction erosion model, but also

222 anticlines and landward-dipping strata (Fig. 7). Normal faults are found throughout the survey

223 area. Line D05 shows a smooth seafloor with normal faults offsetting the sediment fill and a

$224 \sim 500 \mathrm{~m}$ high ridge. Line D09 reveals that normal faults offset the RBU and slope fill but do not

225 extend up to the seafloor. Basin fill thickness of $\sim 1 \mathrm{~km}$ is found near the center of the profile

226 where the seismic amplitude of the RBU becomes weaker and thus forces a less confident

227 interpretation. At line D17, the upper to middle slope transition is sharp, with thickening of the

228 upper slope sediment fill until a steep slope break, after which the slope fill decreases from $\sim 2.5$

$229 \mathrm{~km}$ thick at the seaward edge to $<1 \mathrm{~km}$ thick over a distance of $\sim 5 \mathrm{~km}$. At the slope break, the

230 seafloor and the RBU are offset by multiple normal faults. This steepening of the seafloor and

231 thinning of sediment fill may be caused by submarine landslides (e.g., Kawamura et al., 2012).

232 Line D19, 12 km north of D17, shows a very different morphology. Line D19 shows slope fill

233 that is heavily deformed by normal faults like in D17, but the RBU remains generally 
234 continuous. An anticline on the RBU appears to have a deeper landward-dipping reflection

235 beneath it and deforms the seafloor. Slope fill thickens seaward on line D19 until this anticline

236 and then thins seaward. The acquisition geometry of line D19 within this transition zone has a

237 kink in it, caused by the need to avoid debris in the water, and this kink may cause seismic

238 artifacts. However, line D19 is not the only line in which anticlines and landward-dipping beds

239 are found. Line D03 shows a large anticline on the seaward edge (Fig. 7), $30 \mathrm{~km}$ west of the

240 deformation front. This anticline is $\sim 4-6 \mathrm{~km}$ long along strike and contains a local bathymetric

241 high (Fig. 6). Line D13 shows the seafloor slopes seaward, to the east, but bedding dips landward

242 from the RBU to the overlying forearc basin and has a similar deformational pattern to the basin

243 fill in seismic line D11 (Figs. 3 and 4). The nearby location of these basins and similarities in

244 tilting suggests that this previous tilting event was continuous for greater than $10 \mathrm{~km}$ along-

245 trench. The basin in which lines D11 and D13 are located is bounded to the north by a local

246 bathymetric high where ODP Site 1151 is located (Figs. 3 and 1). This separates the basin of

247 D11 and D13 from the northern basin of line D16, which has a landward-dipping seafloor.

248 Furthermore at line D13, an anticline of $\sim 2.5 \mathrm{~km}$ in width is located on the seaward edge of the

249 landward-dipping strata (Fig. 7), but the RBU contains a broader anticline of $\sim 15 \mathrm{~km}$ wide in this

250 area. Additionally, the seaward edge of the RBU across the survey area generally contains

251 weaker amplitudes and is less continuous, causing a less confident interpretation for the region

252 (Fig. 7). This reoccurring feature may be from changes in the depositional pattern or increased

253 deformation from faults and folds in the region. These disparate seismic profiles across the

254 survey area reveal a complex and nonuniform transition between the upper and middle slope.

255 Both seismic and bathymetric data show normal faults with anticlines interspersed between

256 them, in contrast to previous interpretations of the margin. 


\section{Discussion}

Our results indicate that subduction erosion is not the sole driving force for the

deformation found along the Japan Trench upper slope. The subduction erosion model predicts a

260 landward progression of subsidence as basal erosion migrates arcward with time. Instead, we do

261 not find a consistent deformational pattern for the RBU at the upper slope. The regional

262 subsidence pattern of the Japan Trench margin can be estimated from subducting plate geometry

263 changes due to accelerations in plate converge and decreased plate buoyancy due to extension

264 associated with the opening of the Sea of Japan with peak local convergence rates occurring 10

265 to $30 \mathrm{Ma}$ (Regalla et al., 2013). In the Miocene, the Japan arc and backarc experienced a change

266 from trench-perpendicular extension to shortening (Kato et al., 2006). This onshore shortening

267 may have extended seaward to the upper slope basins (e.g., Regalla et al., 2013), and benthic

268 foraminifera assemblages further indicate shallowing and uplift of the forearc seafloor since 3.5

269 Ma (Arthur et al., 1980). We find both modern and buried basins with strata that dip landward in

270 response to local uplift at the seaward side of each basin, as multiple seismic lines display

271 anticlines in both the RBU and overlying sediments on the seaward edge of these basins (Fig. 3).

272 A subducting seamount is not found on the subducting plate and does not appear to be the cause

273 of these basin formations, with the major subducting features being a horst and graben system

274 (Figs. 1 and 5). Whereas subducting normal faults influence the frontal prism's decollement

275 (Boston et al., 2014), at depth, the subduction plane has been previously interpreted to be above

276 the top of such features (von Huene and Culotta, 1989). Similar basins found north of our survey

277 area were proposed to be formed by a listric normal fault on the landward edge of the basin (von

278 Huene and Culotta, 1989). However, we do not find evidence for a basin-forming listric fault

279 system in the sediment column nor RBU. Such a feature potentially has a limited along-trench 
extent like structures found within our survey area. Normal fault populations at the Japan Trench

281 upper slope have also been suggested to indicate subduction erosion (e.g., von Huene et al.,

282 1994). However, many of the normal faults found in our survey area do not offset the seafloor or 283 overlying forearc basins and thus are not currently active (Figs. 4 and 7). Instead, the proximity 284 of both normal faults and thrusts may indicate periods of alternating faulting style or periods of 285 variable fault formation. The changes in subsidence rates and convergence rates for the upper 286 slope may influence the different faulting styles found along the margin (Scientific Party, 1980;

287 Regalla et al., 2013). These results indicate that subduction erosion needs to be reconsidered as 288 the sole driving force of the deformation found at the Japan Trench upper slope. The middle slope shows a more consistent deformational pattern than the upper slope.

290 The RBU consistently dips seaward and slope fill consistently thins at the middle slope (Fig. 5), 291 whereas the upper slope lacks such uniformity. Additionally, an increase in chaotic reflections in 292 the middle slope may indicate highly deformed strata there. The greater amounts of subsidence at 293 the middle slope cannot fully be explained through changes in plate convergence rates and may 294 be from subduction erosion (Regalla et al., 2013). Therefore, these results indicate a landward 295 limit to major subduction erosion.

296 Many of the deformational processes at the middle slope are still unknown due to poor 297 imaging there. Subducting siliceous sediments at the Japan Trench have a maximized 298 dehydration rate zone of $\sim 50-60 \mathrm{~km}$ from the deformation front (Kimura et al., 2012). This 299 location is near the middle to upper slope boundary, suggesting that this water influx may cause 300 hydrofracturing of the overriding plate and subduction erosion (von Huene et al., 2004) within 301 the middle slope and diminishing on the upper slope. Other velocity models have found a sharp 302 bend in the subducting Pacific Plate, where the subduction angle steepens by $\sim 8^{\circ}$, and the 
303 bending axis located near the upper to middle slope (Fujie et al., 2006; Ito et al., 2005).

304 However, this apparent bend could also be caused by a rough plate interface or earthquakes

305 occurring on subfaults off the main plate boundary fault, with no bend required to explain the

306 data (Zhan et al., 2012). Therefore, the role in the subducting plate bend on the middle slope

307 deformation is still unclear.

308 The middle slope may further play an important role for mass wasting. Previous

309 bathymetry analysis, deep-sea submersible observations, and tsunami modeling indicate potential

310 submarine landslide locations at the middle slope region that may have impacted tsunami

311 generation during the Tohoku event (Kawamura et al., 2012; Tappin et al., 2014). Seafloor

312 steepening and slope fill thinning at the upper to middle slope transition suggests seafloor

313 erosion is present along the middle slope (Figs. 5 and 7). Additionally, seismic reflectors become

314 chaotic within the middle slope implying further deformation. We find no direct evidence of

315 major mass wasting events on the upper slope within our seismic resolution, but middle slope

316 erosion confirms that the upper to middle slope transition is the landward boundary for large

317 mass wasting events.

318 A regional landward-dipping normal fault at the upper to middle slope transition has been

319 inferred to create a pop-up structure during concurrent rupture of both the plate boundary fault

320 and the normal fault (Tsuji et al., 2011; Tsuji et al., 2013). However, this interpretation requires

321 that the normal fault extends horizontally several tens of kilometers in order to vertically extend

322 down to the plate boundary at $\sim 12 \mathrm{~km}$. Our interpretations show that this normal fault has only

323 limited $(\sim 10 \mathrm{~km})$ lateral continuity in our survey area (Figs. 6 and 7$)$. Additionally, the other

324 active seafloor breaching faults also lack regional connectivity, but we still do not fully

325 understand how the deeper faults propagate throughout the margin. After the 2011 Tohoku 
earthquake, normal fault type mechanisms were widely distributed in the overriding plate (Asano

327 et al., 2011), however, a densely-spaced ocean bottom seismograph survey revealed a 45-km-

328 wide aseismic wedge for the overriding prism's toe (Obana et al., 2013). This area also shows a

329 clear velocity contrast between low velocity accreted sediments and a higher velocity backstop

330 for seismic line JFD1 (Nakamura et al., 2014). This presumed backstop interface is within the

331 middle slope, but does not appear to correlate with a bounding normal fault. Due to the range of

332 deformational styles at the upper to middle slope transition and lack of regional fault

333 connectivity, normal faults at the upper to middle slope transition, and their potential pop-up

334 structure, should not be considered an indicator of a regional tsunami source area at the Japan

335 Trench margin.

\section{5. Conclusions}

337 We provide new seismic reflection profiles and interpretations of the Japan Trench

338 margin that investigate tectonic processes in an $\sim 150 \mathrm{~km}$ along-trench region. We find that the

339 middle slope has consistent thinning of slope fill, steepening of the seafloor, and chaotic

340 reflections, signifying a region of major mass wasting events. The upper to middle slope

341 transition shows both extensional and shortening features that lack regional connectivity,

342 indicating that individual normal faults play a limited role in regional deformational processes at

343 the Japan Trench margin. We observe that the regional basal unconformity contains a variable

344 pattern of deformation and that uplift occurred in selected regions, greatly differing from the

345 pattern found at the middle slope. This pattern indicates that a purely erosional model is not

346 appropriate for the Japan Trench margin and that additional tectonic activity has deformed the

347 region, which may have implications for similar behavior at other margins.

\section{Acknowledgments}


Funding was provided through the National Science Foundation (grants OCE-1260718 and

350 OCE-1138051). A part of this study was supported by JSPS Grant-in-Aid for Scientific Research

351 (S) (15H05718). The authors are grateful to the scientists and crews of KR11-05 Leg 2, KR11-

352 E03, KR11-E05, and KR13-01. We thank P. Fryer and S. Martel for their constructive review of

353 an early version of this paper. We thank JGI Inc. for their support in the PSDM analysis. We

354 thank Paradigm Geophysical and Landmark Graphics (Halliburton) for their academic software

355 licenses that made this work possible.

\section{Figure Captions}

357 Figure 1. A. Tectonic setting of the Japan Trench. The red box is the location of Figure 1B, the 358 yellow star shows the 2011 Tohoku earthquake epicenter (Chu et al., 2011), and white arrows

359 show the convergence direction of the Pacific Plate $-\mathrm{PP}=$ Pacific Plate and EP= Eurasian Plate.

360 B. Bathymetry map of the study region. Black lines are seismic profiles with white sections

361 displayed in Figure 3. White dashed curve is the deformation front (Boston et al., 2014). Grey

362 contours show coseismic slip area for the 2011 earthquake (Wei et al., 2012). Diagonally shaded

363 areas are identified as isolated basins (Arai et al., 2014). Green circles are ODP Sites and red

364 circle is IODP Site C0019. The star is the earthquake epicenter. Red box is the location of Figure

365 6. C. Seismic profile D17 with forearc slope morphology, the regional basal unconformity, and

366 subducting Pacific Plate and normal faults marked. The lower slope is the general location of the

367 actively accreting prism.

368 Figure 2. Regional-residual separation of bathymetry. White lines are the seismic profiles and 369 the red or blue dashed line is the deformation front (Boston et al., 2014). A. Regional filtered 370 bathymetry. B. Distribution of median absolute deviation (MAD) values from results in Figure 
371 2A. C. Slope azimuth of the regional bathymetry. Blue circles highlight two landward tilted

372 forearc basins. D. Residual bathymetry.

373 Figure 3. Seismic profiles of landward-dipping basins with locations in Figure 1. The regional

374 basal unconformity is at the top of the green region. Red boxes are locations of the basins shown

375 in Figure 4. Dashed black lines are interpreted horizons, and gray lines mark seafloor breaching

376 normal faults. The seafloor above forearc basins of lines D08 and D16 dip landward with

377 underlying strata also dipping landward. The RBU of line D11 contains an anticline that is also

378 found in the overlying strata, creating a thicker basin west of the anticline.

379 Figure 4. Shallow basins at the Japan Trench forearc. Locations are in Figure 3. The top of the 380 blue region marks the onlapping surface. Normal faults (gray lines) in lines D08 and D16 do not 381 propagate through the overlying basin strata. Line D11 contains buried landward strata following 382 the geometry of deeper horizons.

383 Figure 5. Map view of the RBU, forearc slope sediment thickness map, and Pacific Plate with 384 the seafloor shaded relief plotted on top. A. Smoothed surface of the RBU. Grey lines are the 385 seismic profiles to show interpretation constraints. Black dashed line in all plots is the shape of 386 the deformation front shown for comparison with local trends (note that the deformation front is 387 located $50 \mathrm{~km}$ to the east). B. Isopach map of sediments above RBU. One general trend of 388 thinning near the eastern edge is found throughout the region. However, the overall region shows 389 multiple thicker basins. C. The subducting Pacific Plate smoothed surface from the PSDM lines.

390 Figure 6. Bathymetry and residual bathymetry at the upper to middle slope boundary and 391 structural interpretations. The location of this region is shown in Figure 1B. Black lines are 392 seismic lines with the white sections presented in Figure 7. A. Bathymetry with seismic line 
393 names. B. Residual Bathymetry. C. Seafloor breaching large-scale features constrained from 394 seismic profiles.

395 Figure 7. Seismic profiles of the upper to middle slope transition (left column) and general 396 interpretations (right column) with profile locations in Figure 6. The top of the green region 397 marks the regional basal unconformity with dashed regions having lower certainty. Gray lines 398 are normal faults. The profiles are in the general same location from north to south (Fig. 6), but 399 show a range of morphologies for the area. 
402

403

404

405

406

407

408

409

410

411

412

413

414

415

416

417

418

419

420

421

422

423

424

\section{References}

Arai, K., Inoue, T., Ikehara, K., Sasaki, T., 2014. Episodic subsidence and active deformation of the forearc slope along the Japan Trench near the epicenter of the 2011 Tohoku Earthquake. Earth Planet. Sci. Lett. 408, 9-15. doi:10.1016/j.eps1.2014.09.048.

Arthur, M.A., von Huene, R., Adelseck, C.G., 1980. Sedimentary evolution of the Japan fore-arc region off northern Honshu, Legs 56 and 57, Deep Sea Drilling Project, in: Lee, M., Stout, L.N. (Eds.), Initial Reports of the Deep Sea Drilling Project, Legs 56 and 57 (Part 1),

Washington, D.C., 521-612.

Asano, Y., Saito, T., Ito, Y., Shiomi, K., Hirose, H., Matsumoto, T., Aoi, S., Hori, S., Sekiguchi, S., 2011. Spatial distribution and focal mechanisms of aftershocks of the 2011 off the Pacific coast of Tohoku Earthquake. Earth Planets Space 63, 669-673. doi:10.5047/Eps.2011.06.016.

Bassett, D., Sandwell, D.T., Fialko, Y., Watts, A.B., 2016. Upper-plate controls on co-seismic slip in the 2011 magnitude 9.0 Tohoku-oki earthquake. Nature 531, 92-96. doi:10.1038/nature16945.

Boston, B., Moore, G.F., Nakamura, Y., Kodaira, S., 2014. Outer-rise normal fault development and influence on near-trench décollement propagation along the Japan Trench, off Tohoku. Earth Planets Space 66, 135. doi:10.1186/1880-5981-66-135.

Chu, R., Wei, S., Helmberger, D.V., Zhan, Z., Zhu, L., Kanamori, H., 2011. Initiation of the great Mw 9.0 Tohoku-Oki earthquake. Earth Planet. Sci. Lett. 308, 277-283. doi:10.1016/j.eps1.2011.06.031.

Fujie, G., Ito, A., Kodaira, S., Takahashi, N., Kaneda, Y., 2006. Confirming sharp bending of the Pacific plate in the northern Japan trench subduction zone by applying a traveltime mapping method. Phys. Earth Planet. Inter. 157, 72-85. doi:10.1016/j.pepi.2006.03.013. 
425 Fujie, G., Miura, S., Kodaira, S., Kaneda, Y., Shinohara, M., Mochizuki, K., Kanazawa, T.,

426 Murai, Y., Hino, R., Sato, T., Uehira, K., 2013. Along-trench structural variation and seismic

427 coupling in the northern Japan subduction zone. Earth Planets Space 65, 75-83.

428 doi:10.5047/eps.2012.06.003.

429 Fujii, Y., Satake, K., Sakai, S., Shinohara, M., Kanazawa, T., 2011. Tsunami source of the 2011

430 off the Pacific coast of Tohoku Earthquake. Earth Planets Space 63, 815-820.

431 doi:10.5047/Eps.2011.06.010.

432 Fuller, C.W., Willett, S.D., Brandon, M.T., 2006. Formation of forearc basins and their influence 433 on subduction zone earthquakes. Geology 34, 65-68. doi:10.1130/g21828.1.

434 Hayakawa, T., Kasahara, J., Hino, R., Sato, T., Shinohara, M., Kamimura, A., Nishino, M., Sato,

435 T., Kanazawa, T., 2002. Heterogeneous structure across the source regions of the 1968

436 Tokachi-Oki and the 1994 Sanriku-Haruka-Oki earthquakes at the Japan Trench revealed by

437 an ocean bottom seismic survey. Phys. Earth Planet. Inter. 132, 89-104. doi:10.1016/S0031-

$438 \quad 9201(02) 00046-8$.

439 Hooper, A., Pietrzak, J., Simons, W., Cui, H., Riva, R., Naeije, M., Terwisscha van Scheltinga,

440 A., Schrama, E., Stelling, G., Socquet, A., 2013. Importance of horizontal seafloor motion on

441 tsunami height for the $2011 \mathrm{Mw}=9.0$ Tohoku-Oki earthquake. Earth Planet. Sci. Lett. 361,

$442 \quad$ 469-479. doi:10.1016/j.eps1.2012.11.013.

443 Ide, S., Baltay, A., Beroza, G.C., 2011. Shallow dynamic overshoot and energetic deep rupture in

444 the $2011 \mathrm{Mw} 9.0$ Tohoku-Oki earthquake. Science 332, 1426-1429.

445 doi:10.1126/science.1207020.

446 Ito, A., Fujie, G., Miura, S., Kodaira, S., Kaneda, Y., Hino, R., 2005. Bending of the subducting

447 oceanic plate and its implication for rupture propagation of large interplate earthquakes off 
Miyagi, Japan, in the Japan Trench subduction zone. Geophys. Res. Lett. 32. doi:10.1029/2004gl022307.

Kato, N., Sato, H., Umino, N., 2006. Fault reactivation and active tectonics on the fore-arc side of the back-arc rift system, NE Japan. J. Struct. Geol. 28, 2011-2022. doi:10.1016/j.jsg.2006.08.004.

Kawamura, K., Sasaki, T., Kanamatsu, T., Sakaguchi, A., Ogawa, Y., 2012. Large submarine landslides in the Japan Trench: A new scenario for additional tsunami generation. Geophys. Res. Lett. 39, L05308. doi:10.1029/2011g1050661.

Kim, S.-S., Wessel, P., 2008. Directional median filtering for regional-residual separation of bathymetry. Geochem. Geophys. Geosyst. 9, Q03005. doi:10.1029/2007gc001850.

Kimura, G., Hina, S., Hamada, Y., Kameda, J., Tsuji, T., Kinoshita, M., Yamaguchi, A., 2012.

Runaway slip to the trench due to rupture of highly pressurized megathrust beneath the middle trench slope: The tsunamigenesis of the 2011 Tohoku earthquake off the east coast of northern Japan. Earth Planet. Sci. Lett. 339-340, 32-45. doi:10.1016/j.eps1.2012.04.002.

Kirkpatrick, J.D., Rowe, C.D., Ujiie, K., Moore, J.C., Regalla, C., Remitti, F., Toy, V., WolfsonSchwehr, M., Kameda, J., Bose, S., Chester, F.M., 2015. Structure and lithology of the Japan Trench subduction plate boundary fault. Tectonics 34, 53-69. doi:10.1002/2014tc003695.

Kodaira, S., No, T., Nakamura, Y., Fujiwara, T., Kaiho, Y., Miura, S., Takahashi, N., Kaneda, Y., Taira, A., 2012. Coseismic fault rupture at the trench axis during the 2011 Tohoku-oki earthquake. Nat. Geosci. 5, 646-650. doi:10.1038/Ngeo1547.

Mori, N., Takahashi, T., Yasuda, T., Yanagisawa, H., 2011. Survey of 2011 Tohoku earthquake tsunami inundation and run-up. Geophys. Res. Lett. 38, L00G14. doi:10.1029/2011g1049210. 
Nakamura, Y., Kodaira, S., Miura, S., Regalla, C., Takahashi, N., 2013. High-resolution seismic 471 imaging in the Japan Trench axis area off Miyagi, northeastern Japan. Geophys. Res. Lett. 40, 1713-1718. doi:10.1002/grl.50364.

473 Nakamura, Y., Kodaira, S., Cook, B.J., Jeppson, T., Kasaya, T., Yamamoto, Y., Hashimoto, Y., 474 Yamaguchi, M., Obana, K., Fujie, G., 2014. Seismic imaging and velocity structure around 475 the JFAST drill site in the Japan Trench: low Vp, high Vp/Vs in the transparent frontal prism. Earth Planets Space 66, 121. doi:10.1186/1880-5981-66-121.

477 Obana, K., Kodaira, S., Shinohara, M., Hino, R., Uehira, K., Shiobara, H., Nakahigashi, K., 478 Yamada, T., Sugioka, H., Ito, A., Nakamura, Y., Miura, S., No, T., Takahashi, N., 2013. 479 Aftershocks near the updip end of the 2011 Tohoku-Oki earthquake. Earth Planet. Sci. Lett. $480 \quad 382,111-116$. doi:10.1016/j.eps1.2013.09.007.

481 Regalla, C., Fisher, D.M., Kirby, E., Furlong, K.P., 2013. Relationship between outer forearc 482 subsidence and plate boundary kinematics along the Northeast Japan convergent margin. 483 Geochem. Geophys. Geosyst. 14, 5227-5243. doi:10.1002/2013gc005008. Govt. Printing Office). doi:10.2973/dsdp.proc.5657.1980. Office). doi:10.2973/dsdp.proc.87.105.1986.

489 Simons, M., Minson, S.E., Sladen, A., Ortega, F., Jiang, J., Owen, S.E., Meng, L., Ampuero, 490 J.P., Wei, S., Chu, R., Helmberger, D.V., Kanamori, H., Hetland, E., Moore, A.W., Webb, 491 F.H., 2011. The 2011 magnitude 9.0 Tohoku-Oki earthquake: mosaicking the megathrust 492 from seconds to centuries. Science 332, 1421-1425. doi:10.1126/science.1206731. 
493

494

495

496

497

498

499

500

501

502

503

504

505

506

507

508

509

510

511

512

513

514

515

Song, T.R., Simons, M., 2003. Large trench-parallel gravity variations predict seismogenic behavior in subduction zones. Science 301, 630-633. doi:10.1126/science.1085557.

Suyehiro, K., Sacks, I.S., Acton, G.D., Oda, M., 2003. Proc. ODP, Sci. Results, 186, College

Station, TX (Ocean Drilling Program). doi:10.2973/odp.proc.sr.186.2003.

Tanioka, Y., Satake, K., 1996. Tsunami generation by horizontal displacement of ocean bottom. Geophys. Res. Lett. 23, 861-864. doi:10.1029/96g100736.

Tappin, D.R., Grilli, S.T., Harris, J.C., Geller, R.J., Masterlark, T., Kirby, J.T., Shi, F., Ma, G., Thingbaijam, K.K.S., Mai, P.M., 2014. Did a submarine landslide contribute to the 2011 Tohoku tsunami? Mar. Geol. 357, 344-361. doi:10.1016/j.margeo.2014.09.043.

Tsuji, T., Ito, Y., Kido, M., Osada, Y., Fujimoto, H., Ashi, J., Kinoshita, M., Matsuoka, T., 2011. Potential tsunamigenic faults of the 2011 off the Pacific coast of Tohoku Earthquake. Earth Planets Space 63, 831-834. doi:10.5047/eps.2011.05.028.

Tsuji, T., Kawamura, K., Kanamatsu, T., Kasaya, T., Fujikura, K., Ito, Y., Tsuru, T., Kinoshita, M., 2013. Extension of continental crust by anelastic deformation during the 2011 Tohoku-oki earthquake: The role of extensional faulting in the generation of a great tsunami. Earth Planet. Sci. Lett. 364, 44-58. doi:10.1016/j.eps1.2012.12.038.

Tsuru, T., Park, J.O., Takahashi, N., Kodaira, S., Kido, Y., Kaneda, Y., Kono, Y., 2000. Tectonic features of the Japan Trench convergent margin off Sanriku, northeastern Japan, revealed by multichannel seismic reflection data. J. Geophys. Res. 105, 16403-16413. doi:10.1029/2000jb900132.

Tsuru, T., Park, J.O., Miura, S., Kodaira, S., Kido, Y., Hayashi, T., 2002. Along-arc structural variation of the plate boundary at the Japan Trench margin: Implication of interplate coupling. J. Geophys. Res. 107, 2357. doi:10.1029/2001jb001664. 
von Huene, R., Arthur, M.A., 1982. Sedimentation across the Japan trench off northern Honshu

517 Island. Geological Society, London, Special Publications 10, 27-48.

518 doi:10.1144/GSL.SP.1982.010.01.02.

519 von Huene, R., Langseth, M., Nasu, N., Okada, H., 1982. A summary of Cenozoic tectonic

520 history along the IPOD Japan Trench transect. Geol. Soc. Am. Bull. 93, 829.

521 doi:10.1130/0016-7606(1982)93<829:asocth>2.0.co;2.

522 von Huene, R., Culotta, R., 1989. Tectonic erosion at the front of the Japan Trench convergent

523 margin. Tectonophysics $160,75-90$.

524 von Huene, R., Klaeschen, D., Cropp, B., Miller, J., 1994. Tectonic structure across the

525 accretionary and erosional parts of the Japan Trench margin. J. Geophys. Res. 99, 22349-

526 22361. doi:10.1029/94JB01198.

527 von Huene, R., Ranero, C.R., Vannucchi, P., 2004. Generic model of subduction erosion.

$528 \quad$ Geology 32, 913-916. doi:10.1130/g20563.1.

529 Wei, S.J., Graves, R., Helmberger, D., Avouac, J.P., Jiang, J.L., 2012. Sources of shaking and

530 flooding during the Tohoku-Oki earthquake: A mixture of rupture styles. Earth Planet. Sci.

$531 \quad$ Lett. 333, 91-100. doi:10.1016/J.epsl.2012.04.006.

532 Wells, R.E., Blakely, R.J., Sugiyama, Y., Scholl, D.W., Dinterman, P.A., 2003. Basin-centered

533 asperities in great subduction zone earthquakes: A link between slip, subsidence, and

$534 \quad$ subduction erosion? J. Geophys. Res. 108, 2507. doi:10.1029/2002jb002072.

535 Yilmaz, Ö., 2001. Seismic Data Analysis: Processing, Inversion, and Interpretation of Seismic

536 Data. SEG, Tulsa, OK. doi:10.1190/1.9781560801580.

537 Zhan, Z., Helmberger, D., Simons, M., Kanamori, H., Wu, W., Cubas, N., Duputel, Z., Chu, R.,

538 Tsai, V.C., Avouac, J.-P., Hudnut, K.W., Ni, S., Hetland, E., Culaciati, F.H.O., 2012. 
539 Anomalously steep dips of earthquakes in the 2011 Tohoku-Oki source region and possible

540 explanations. Earth Planet. Sci. Lett. 353-354, 121-133. doi:10.1016/j.eps1.2012.07.038.

541

542 
543 List of Abbreviations

544 DSDP Deep Sea Drilling Project

545 IODP Integrated Ocean Drilling Program

546 ODP Ocean Drilling Program

547 RBU Regional Basal Unconformity 


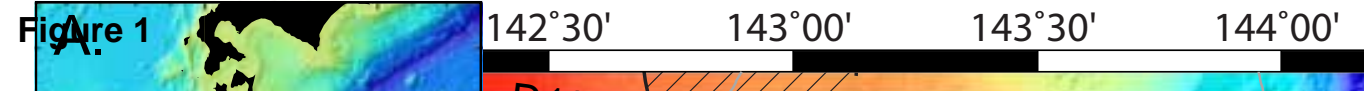

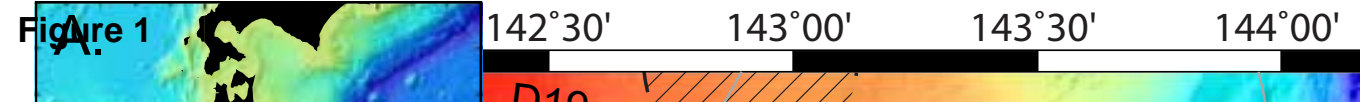
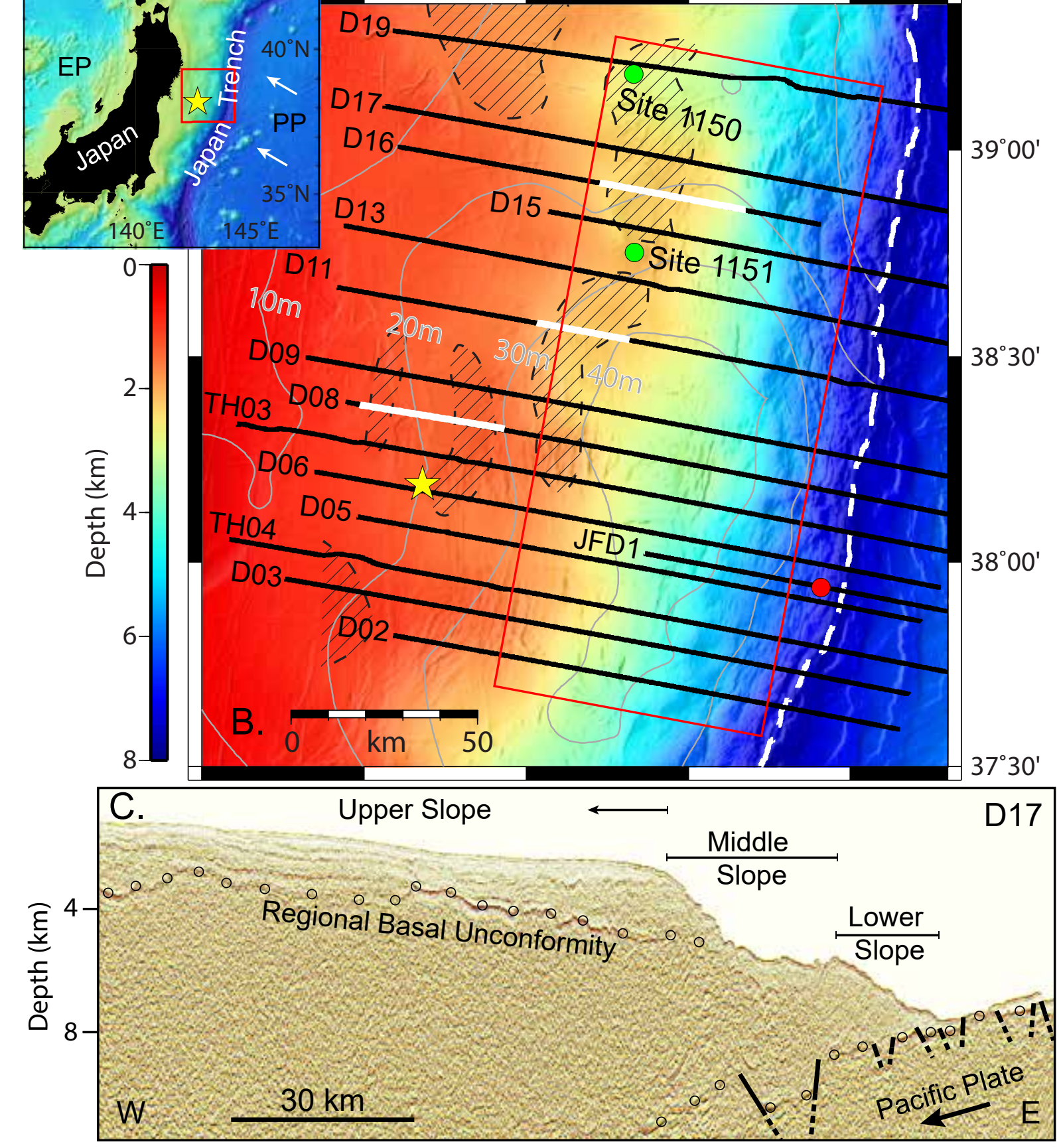


\section{Figure $\sqrt{3}$}
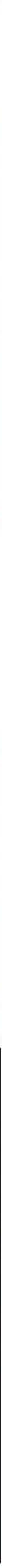
Fialtfe' $35^{\prime} \quad 143^{\circ} 00^{\prime} \quad 143^{\circ} 30^{\prime}$

$142^{\circ} 30^{\prime} \quad 143^{\circ} 00^{\prime} \quad 143^{\circ} 30^{\prime}$
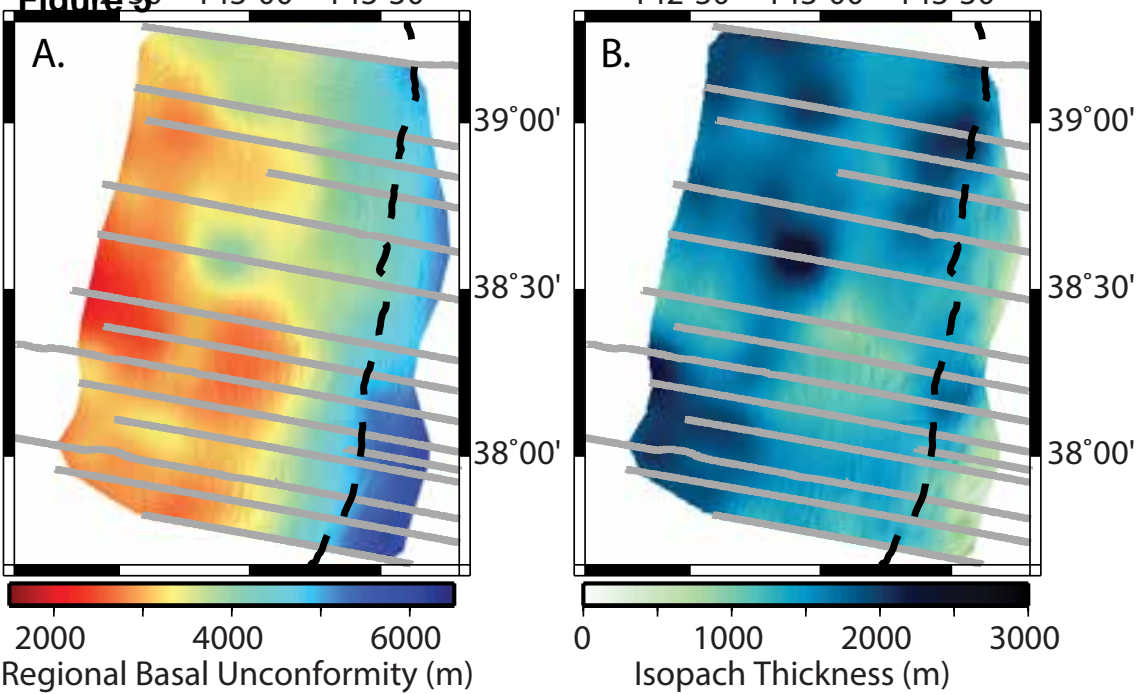

$142^{\circ} 30^{\prime} \quad 143^{\circ} 00^{\prime} \quad 143^{\circ} 30^{\prime}$

B.

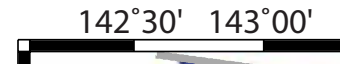

C. 0

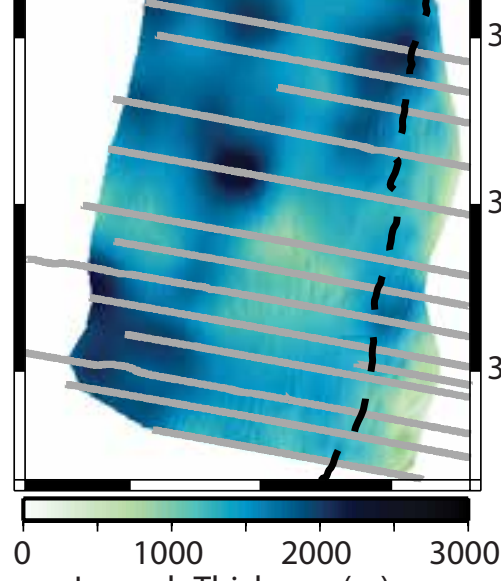

Isopach Thickness (m)

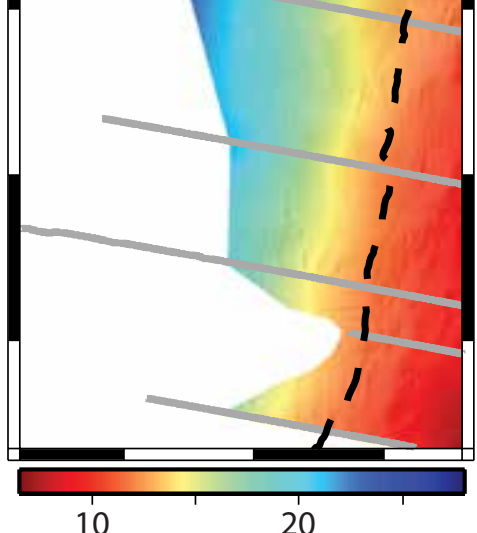

10

Pacific Plate (km)
C. -1 
Aigure3 ${ }^{6} 24^{\prime}$

$143^{\circ} 48^{\prime}$

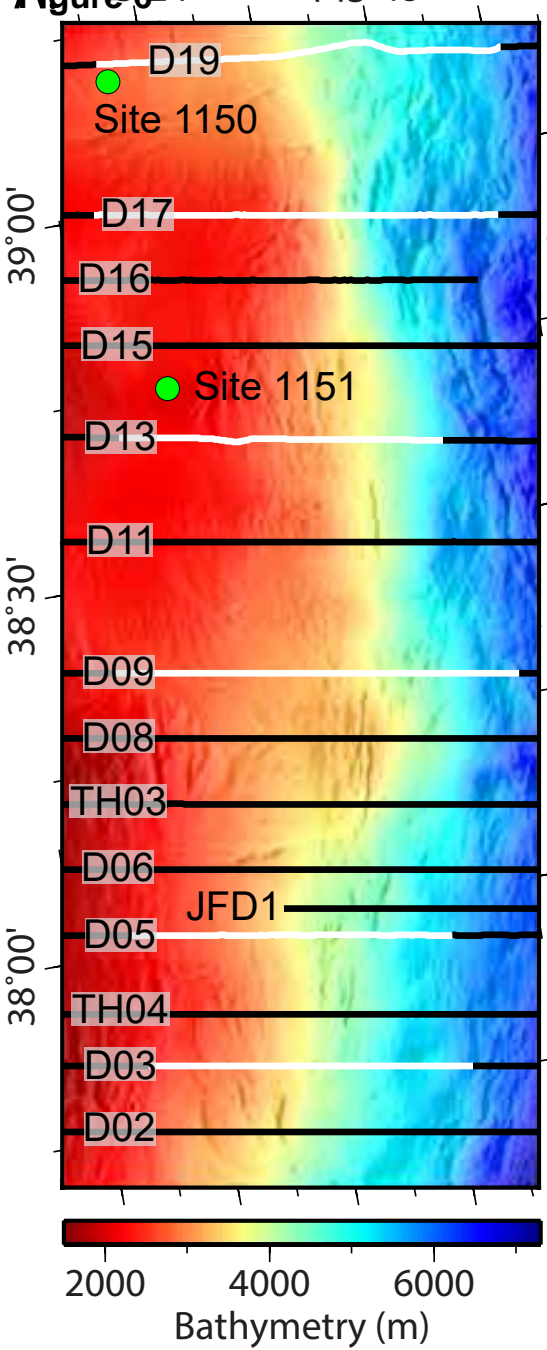

B. $143^{\circ} 24^{\prime}, 143^{\circ} 48^{\prime}$

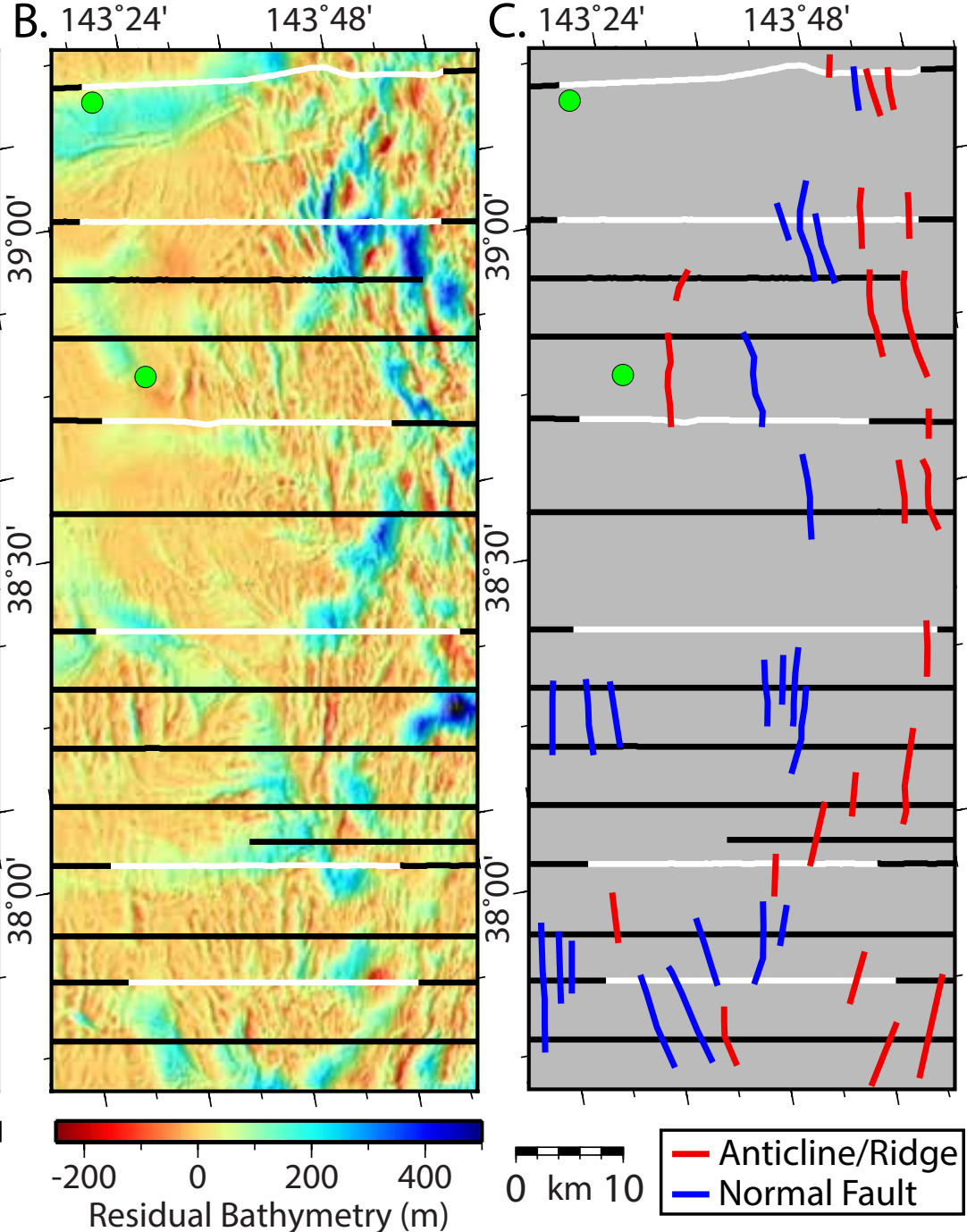


